\title{
Paideusis
}

\section{"Ethical Judgement in Teaching" (Karl D. Hostetler)}

\section{Sandra Bruneau}

Volume 11, Number 2, 1998

URI: https://id.erudit.org/iderudit/1073106ar

DOI: https://doi.org/10.7202/1073106ar

See table of contents

Publisher(s)

Canadian Philosophy of Education Society

ISSN

0838-4517 (print)

1916-0348 (digital)

Explore this journal

Cite this review

Bruneau, S. (1998). Review of ["Ethical Judgement in Teaching" (Karl D.

Hostetler)]. Paideusis, 11(2), 73-77. https://doi.org/10.7202/1073106ar

(c) Sandra Bruneau, 1998

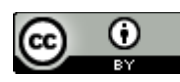

This document is protected by copyright law. Use of the services of Erudit (including reproduction) is subject to its terms and conditions, which can be viewed online.

https://apropos.erudit.org/en/users/policy-on-use/
This article is disseminated and preserved by Érudit.

Érudit is a non-profit inter-university consortium of the Université de Montréal, Université Laval, and the Université du Québec à Montréal. Its mission is to promote and disseminate research.

https://www.erudit.org/en/ 


\section{Book Reviews}

\section{Karl D. Hostetler. Ethical Judgment in Teaching. Needham Heights, MA: Allyn \& Bacon, 1997. 229 pp.}

Hostetler's book is as organized, comprehensive, and as involving as a play in several acts. It begins with a rationale for exploring ethical judgments in teaching and ends with short essays on the same theme. There is even a denouement consisting of case studies on additional teacher education topics. Between the volume's beginning and end are a series of imagined school situations or case studies and analytical essays on the ethical implications of school problems with revealing discussions about disagreements over meanings and priorities in classroom practice. Hostetler wants to show readers, teachers, community members, post-secondary students, and scholars how to see and to resolve ethical conflicts in education. He expects those who face perplexing situations are will be better able to handle them if they understand ethics and ethical judgment.

Most educational problems, he maintains, have ethical components which can be viewed from the ethical point of view-even small things teachers do such as choosing items for a bulletin board, arranging desks, practising certain rituals call for ethical judgment. But the most important educational decisions, and some of the most contentious, have various peoples' interests at the core. Often, these interests conflict. Fostering educators' abilities to make good ethical judgments about teaching and learning conditions and practices, Hostetler suggests, means encouraging them to think about and to appreciate others' points of view. This may lead educators to uncover diverse beliefs, opinions, reasons, and principles. All of us can tackle appropriately the problems we face in education, Hostetler believes, if we learn to reason with reference to ethical norms, standards, and practices and are disposed to analyze the relevant con-
cepts.

Hostetler wants us to see the complexity of educational problems and to have due regard for those who are or who may be affected by our decisions. He is equally concerned about maintaining values and adhering to duty. Leaming to do this well, he suggests, means learning how to make good ethical judgments. Hostetler's thesis is that ethical judgment, perception, caring, and reflection are inextricably linked.

We should not mistake ethical judgment, however, with being judgmental. Nor is making an ethical judgment a simple affair: rarely does one just "see" what is right or good. Ethical judgment-making is not just the "uncovering" or "discovery" of answers to our dilemmas; problems "have to be hashed out." Nor, he says, is judgment the same as just thinking about a problem since judgment implies "some evaluation of the objects of thought." Judgment is a discriminating and normative form of thought or reflection, and it should not be confused with reflection, "since reflection does not always involve the vital activity of judgment and discrimination." But judgment also differs from calculation even though both are non-capricious. Judgment, Hostetler argues, is best described as "know-how about when and when not to apply a rule." And frequently, there is no rule "that clinches [a] decision one way or the other." Judgment, he says, enters into ethical deliberations at three points: in determining what is relevant and important for people, for values, or facts about a 
case; in deciding how we should serve or respond to each of these; and in determining what we should do when values and/or persons' responses to values conflict.

Although Hostetler's primary interest is in ethical judgment, he underlines his interest in ethical character as well. "We are," he says, "concerned with the sort of people [teachers] are, what they do, and why they do what they do" (p. 5). Hostetler maintains that even if we were to regard caring and accommodation of others and others' points of view as more important than "ethical judgment," judgment would still have its place, "since there is always a place for thoughtfulness and discernment."

Hostetler realizes that each reader's experience of educational issues and arguments, if not their understanding of ethics, differs. He has organized his book as a forum of sorts for reasoning about the issues. Readers are led to reflect on a range of expert opinions and to consider questions following the opinion pieces. The author offers his own analysis of the issues and of contributors' arguments. As author and teacher, Hostetler wants readers to engage reflectively each step of the way on choices open to all of us who experience the puzzling issues and conflicts in education.

\section{Themes, plots, and characters}

The author attempts this ambitious programme by selecting six themes or "dialectics" in ethics and education: freedom and discipline, self and others, communities near and far, excellence and equality, unity and diversity, faith and truth. Each chapter begins with a detailed case study from a theme, and is followed by responses to the case from two philosophers of education. These discussions open one or more ethical judgments to scrutiny by the invited writers. Each chapter closes with the author's reflections on his guests' essays. He highlights the main ideas, offers expansion of points, places issues in the context of ethical theory, and challenges the writers about their claims.

In the chapter on equality and excellence, for example, a case is presented in which the teacher, Connie, questions both the notion of excellence and the distribution of excellence in her classroom. Two philosophers weigh in with their assessments and then respond in friendly fashion to the other's analysis. The author presents his views of the writers' arguments, highlighting their points of similarity and difference, stressing what is noteworthy in their analyses, including interpretations of key concepts. Finally, the author invites readers to challenge the authors' underlying values and beliefs, and at least some of their conclusions.

In Hostetler's other cases, we meet more teachers: Mary Ann, who opposes the notion that creationism be given equal time with evolutionary theory in her science classes; Sally, troubled by the lack of tolerance towards immigrants in her community; Stan, whose commitment to a relief agency crowds his commitment to students; Lucy, who opposes a policy on testing but who is faced with a dilemma about how, or even if, to express her opposition. All have a ring of familiarity; what is not so familiar is each protagonist's open analysis, then reading philosophers' analyses of the dilemma each faces. 


\section{Hostetler and audience.}

Hostetler's volume is more than an edited collection of papers. Designed primarily for post-secondary classrooms, it is suitable for both pre-service and inservice teacher education courses. Hostetler's choice of themes, his sense of story-telling, his provocative questions, and the give-and-take of his writers' "discussions" make the volume a compelling read.

Hostetler's teaching experience and work as philosopher of education inform the entire work. He is to be commended for tackling some nagging and rather delicate issues in education. Hostetler has invited several American philosophers of education as his writers in residence: Nicholas Burbules, Michael Katz, Nel Noddings, Harvey Siegel, Alven Neiman, Emile Robertson, Shirley Pendlebury, Dilafruz Williams, Susan Laird, and others. The author himself makes use of the work of a number of general philosophers and philosophers of education: Max Weber (on the ethics of intention and of responsibility), Martha Nussbaum (on perception, sensitivity, and discernment), Nel Noddings (on receptiveness to others), John Dewey (on the effectiveness of ethical reflection on remaking habits), Ludwig Wittgenstein (on gaining knowledge and correct judgment-making through experience), and so on. But both the author and his writers may make too little use of the main figures in general and specific studies of ethics.

In my view, the book would have been even more useful and enlightening about the field of ethics had it included more quotations and writings by those who have written extensively in ethics and on Hostetler's themes. Further, the volume would have had wider appeal had Hostetler invited as writers philosophers of education and philosophers of ethics from outside his own country. As it is, this volume suffers from more than a little parochialism. All the writers are from a relatively narrow band of professional philosophers of education in the U.S.A. who tend to drink each other's bathwater in successive edited volumes and conferences.

Still, instructors of courses on professional and ethical issues in teaching could make good use of the book, or at any rate some case studies and essays in it. To Hostetler's credit, he has organized the book to encourage conversation. As he points out, "[the reader's task] is to ponder how the writers do or do not make sense of ethics and to begin to develop an informed, well-considered understanding of ethics and its place in teaching" (p. 6). Whether they do so would depend, in part, on whether readers are encouraged to explore further the issues, and how well-prepared instructors are at leading discussions and educating about ethics. Hostetler's volume whets the appetite, and that is both a compliment and a complaint.

The book has troublesome features all too typical of attempts to inform and enlighten education decision-makers about ethics. By Hostetler's admission, "People who see no point in being ethical will not be convinced by this book," and, "The book is for [those] who already appreciate the point of ethics" (p. 2). Given this observation, Hostetler might have prepared a case that featured participants in formal education (teachers and students, for example), some of whom are disposed to "take the ethical point of view" and others who are not so inclined. Professional writers and philosophers of education might have analyzed the problem teachers and administrators face everyday-that of convincing disbelievers about ethics and about serious engagement in ethical 
reasoning and judgment. Of course, a discussion such as this might still only be read by those interested in the first place, but analyses of a case such as this could suggest different avenues and lines of argument for teachers and others as they greet an increasingly skeptical public seemingly bent on expediency and mass consumption of goods, marks, and status.

A problem in all case studies appears in this volume. Hostetler acknowledges that readers may feel they do not know enough to decide the cases given. Such a reaction, he reassures us, is a legitimate response, although he thinks that an "appeal to lack of knowledge does not always justify indecision on an ethical matter"'(p. 11). Hostetler might have done more, however, to indicate ways readers could find out more information about the problems he sets before deciding them. At the least, there needs to have been protagonists in the cases and in the analytical essays who are inclined to find out more about circumstances and consequences before deciding. Readers need to see not just that indecision in certain situations demands a certain restraint and respect, but that additional fact-gathering is crucial to good ethical judgment. I would like to have seen characters in Hostetler's cases explore issues by digging for more facts and showing how they might order those facts.

He also says "the book aims to ... develop a sense of the value, [and] the possible limitations, of ethical judgment" (p. 9). Certainly, there are many limitations on ethical judgment and pressures to regard other matters in schools as more important. But readers of this book might find the arguments of these essayists too complex, too wrapped in jargon, too off-putting, non-inspiring. On the other hand, Hostetler provides a useful service to those in education by attempting to combine ethical judgment with other "large" themes-namely, rights and duties, which are "paradigmatically ethical matters"; consequentialism and nonconsequentialism; virtues which, he says, should be added to discussions of duties and rights; and ethical values like fairness, courage, safety, trust, loyalty, and the emotions (p. 4). The question is whether Hostetler has been successful with his programme.

On the positive side, however, Hostetler's book is all about the need in education for ethical judgment. He presses teachers and educators to take stands, to sort through ethical beliefs, to make discriminations between what is ethically desirable and what is not. With all of these lofty goals, readers and reviewers do not quarrel.

The stage is set. As Hostetler observes, and as we in Canada are nearly prepared to admit, teacher preparation programmes need to get away from transmission styles of teaching and the notion that learning to teach is learning series of gimmicks and "how-to-do's." Instead, these programmes need to move towards promoting in students independence of thought and self-critical analyses. Curiously, teacher education institutions in this country may not be keeping up with changes in some school curricula, those aimed at developing students' critical thinking. In pre-service programmes in particular, we need to act wisely and quickly to prepare teachers to foster critical thinking in their students. One important way to do this is to expect new teachers to engage in critical thinking themselves, and this should begin in university classrooms.

Certainly, there is a great need for new teaching professionals to become aware of and proficient at making good ethical judgments. All too often, those of us involved in teacher education assume that new teachers either have good 
judgment-making ability or will come to have it without much assistance by the end of their formal preparation. But we should not just assume new teachers will "find" or just develop their good judgment-making abilities. As Hostetler argues, much of good judgment-making involves seeing things in particular ways. We should ask ourselves, therefore, whether what we do in our teacher education programmes is likely to help new teachers respond appropriately to situations and to move forward.

Hostetler's valuable service, then, is to convince readers that ethical judgment-making is part of being a good critical thinker and a good teacher. He is correct, $I$ think, in saying that very little overt attention is paid by teacher education programmes to ethical judgment in teaching although in faculties of education across the country, we do place emphases on ethics-related policies in different subject areas (such as integration of special needs students into classrooms, priorities for funding school programmes, and so on). We also expect student teachers not only to be aware of but to reach ideal standards of performance and personal interaction.

\section{Reviewed by Sandra Bruneau, University of British Columbia}

\section{Patricia White. Civic Virtues and Public Schooling. New York: Teachers \\ College Press, 1996.}

In the high school I attended, every student was required to take one, but only one civics course. The brevity of the school's attention to matters of civic education as well as its indifference to the qualifications of those who taught it-in my school civics was taught by the guidance counsellor-no doubt reflected the idea that the formation of citizens was a straightforward matter of providing information about government coupled with conventional moralizing. It is one merit of Patricia White's new book that it avoids any kind of moralizing. It is yet another that the approach to civic education does not place emphasis on learning about the machinery of government, but rather considers how the school may contribute to the formation of those dispositions of character which are necessary to the maintenance and flourishing of the values characteristic of a democratic polity. In taking this approach, White hopes that we will no longer view civic education as unproblematic and, thus, will allow teachers time and opportunity to reflect on the ethical complexities which arise in connection with a virtue based civic education.

Surprisingly, her treatment of the civic virtues does not include qualities such as justice and tolerance, but rather deals with items such as hope, confidence, self-respect and self-esteem, friendship, trust, honesty, and decency. Her reason for this unusual selection is that these latter qualities have, undeservedly, received far less attention in the literature than have justice and tolerance. Yet, she does devote a chapter to courage, which, like the virtue of justice, has been the subject of a substantial literature. Also absent is any treatment of practical wisdom (phronesis) which, it can be argued, is at the heart of any education which seeks to foster the virtues. Indeed, much of the ethical complexity which White shows to be part of civic life and civic education, seems to call out for some explicit treatment of how the fostering of practical wisdom might be achieved. 